J.R. Schmid - A.B. Bolten

K.A. Bjorndal · W.J. Lindberg

\title{
Activity patterns of Kemp's ridley turtles, Lepidochelys kempit, in the coastal waters of the Cedar Keys, Florida
}

Received: 4 April 2001 / Accepted: 17 August 2001 / Published online: 10 November 2001

(C) Springer-Verlag 2001

\begin{abstract}
Radio and sonic telemetry were used to investigate the tidal orientation, rate of movement (ROM), and surfacing behavior of nine Kemp's ridley turtles, Lepidochelys kempii, tracked east of the Cedar Keys, Florida. The mean of mean turtle bearings on incoming $\left(48 \pm 49^{\circ}\right)$ and falling $\left(232 \pm 41^{\circ}\right)$ tides was significantly oriented to the mean directions of tidal flow (37 $\pm 9^{\circ}, P<0.0025$, and $234 \pm 9^{\circ}, P<0.005$, respectively). Turtles had a mean ROM of $0.44 \pm 0.33 \mathrm{~km} / \mathrm{h}$ (range: $0.004-1.758 \mathrm{~km} / \mathrm{h}$ ), a mean surface duration of $18 \pm 15 \mathrm{~s}$ (range: $1-88 \mathrm{~s}$ ), and a mean submergence duration of $8.4 \pm 6.4 \mathrm{~min}$ (range: $0.2-60.0 \mathrm{~min}$ ). ROM was negatively correlated with surface and submergence durations and positively correlated with the number of surfacings. Furthermore, ROMs were higher and surface
\end{abstract}

Communicated by P.W. Sammarco, Chauvin

Electronic supplementary material to this paper can be obtained by using the Springer LINK server located at http://dx.doi.org/ $10.1007 / \mathrm{s} 002270100708$

J.R. Schmid (冈)

Department of Wildlife Ecology and Conservation,

University of Florida, Gainesville, FL 32611, USA

E-mail: jeffs@conservancy.org

Tel.: + 1-941-2620304

Fax: + 1-941-2620672

J.R. Schmid

U.S. Department of Commerce,

National Oceanic and Atmospheric Administration,

National Marine Fisheries Service,

Southeast Fisheries Science Center,

Miami, FL 33149, USA

J.R. Schmid $\cdot$ A.B. Bolten $\cdot$ K.A. Bjorndal

Archie Carr Center for Sea Turtle Research,

University of Florida, Gainesville, FL 32611, USA

W.J. Lindberg

Department of Fisheries and Aquatic Sciences,

University of Florida, Gainesville, FL 32611, USA

Current address: J.R. Schmid

The Conservancy of Southwest Florida,

1450 Merrihue Drive, Naples, FL 34102, USA and submergence durations were shorter during the day. Daily activities of turtles were attributed to food acquisition and bioenergetics.

\section{Introduction}

Understanding animal activity patterns requires information on the environmental conditions in which the activities occur, as rhythmic patterns in the natural environment are a major influence underlying the behavioral patterns of animals (Nieuwolt 1996). Each species adapts to diel and seasonal changes in the physical factors of the environment, such as illumination and temperature, and these adaptations are reflected in the activity patterns of the species (Gourley 1979). Coastal marine fish commonly exhibit daily activity patterns in response to predictable changes in light and tidal cycles, and these patterns have adaptive significance with respect to bioenergetics and niche definition (Colton and Alevizon 1983; Gruber et al. 1988; Nixon and Gruber 1988; Morrisey 1991). For vertebrate taxa, in general, the biological advantages of rhythmic activity are often determined by secondary ecological factors such as predation and food acquisition (Cloudsley-Thompson 1961).

Telemetric techniques are commonly employed to describe the movements and activities of free-ranging animals, and these descriptions are then used to test for correlations between the observed behaviors and environmental conditions (White and Garrott 1990). Radio, sonic, and satellite telemetry have been used to investigate the activities of Kemp's ridley turtles, Lepidochelys kempii, though the primary goal of most studies has been to describe seasonal activities (Renaud 1995; Gitschlag 1996; Morreale and Standora 1998). Studies of Kemp's ridley turtle behavior have focused on seasonal and diel patterns of surface and submergence durations (Byles 1988; Renaud 1995; Gitschlag 1996). These efforts have produced conflicting results because of differences in the methodologies, small numbers of 
turtles tracked in each study, and substantial individual variation among the turtles. A few investigators have described the localized movements of Kemp's ridley turtles in coastal estuaries (Byles 1988; Danton and Prescott 1988; Morreale and Standora 1998). With respect to environmental influences, Byles (1988) indicated that the daily movements of loggerhead turtles, Caretta caretta, were strongly influenced by the tidal cycle, whereas Kemp's ridley turtles did not range as far with the tide. Increased diurnal movements (Standora et al. 1989) and increased crepuscular dive frequencies (Morreale and Standora 1998) have been suggested for Kemp's ridley turtles, but the authors did not provide data to substantiate their inferences.

The eastern Gulf of Mexico, particularly the Cedar Key area of western Florida, has been identified as an important developmental region for Kemp's ridley turtles (Carr 1957; Bjorndal and Bolten 1990; Thompson et al. 1990; U.S. Fish and Wildlife Service and National Marine Fisheries Service 1992). Relatively little is known about the activities of turtles in this area other than anecdotes from fishermen and observations from markrecapture studies (Carr and Caldwell 1956; Schmid 1998). Discerning daily activity patterns and factors influencing these patterns would not only benefit conservation and management efforts for this highly endangered species, but would also provide insight into the ecological roles of Kemp's ridley turtles in coastal habitats (Bjorndal and Bolten 1990; Thompson et al. 1990). The purpose of the present study is to test hypotheses concerning tidal orientation and diel patterns of movement and surfacing behavior of Kemp's ridley turtles in the coastal waters of the Cedar Keys, Florida.

Fig. 1 Map of west-central Florida showing the Cedar Keys study area. Circle represents the tracking area

\section{Materials and methods}

Data collection

\section{Marine turtle capture}

The study was conducted in Waccasassa Bay, which is located on the west coast of Florida and east of the Cedar Keys (Fig. 1). A large-mesh entanglement net $(65 \mathrm{~m}$ length, $51 \mathrm{~cm}$ stretch mesh, and 20 meshes deep) was used to capture Kemp's ridley turtles near Corrigan Reef. The net was set in areas of aggregation identified by Schmid (1998) and retrieved upon capture of a turtle. Straight-line carapace length (SCL; nuchal notch to tip of postcentral scutes) was measured to the nearest 0.1 in $(2.54 \mathrm{~cm})$ with forester's calipers, and mass was measured to the nearest $0.25 \mathrm{lb}(113.4 \mathrm{~g})$ with a spring scale. Measurements were converted to metric for analysis. Turtles were tagged with Inconel tags, one on each fore flipper, and a passive integrated transponder (PIT) tag was inserted in the left front flipper. Turtles were held on board the tracking vessel for less than $5 \mathrm{~h}$ prior to release.

\section{Radio and sonic telemetry}

Each turtle was instrumented with a CHP-87-L sonic transmitter (Sonotronics, Tucson, Ariz.) and a MOD-050 radio transmitter with a TA-7 antenna (Telonics, Mesa, Ariz.). Sonic transmitters $(32-44 \mathrm{kHz}$ range with constant or coded pulse interval) were attached to posterior marginal scutes. Stainless steel wire was looped through the ends of the transmitter; plastic ties were inserted through the loops and through holes drilled in the scutes and underlying bone. Sonic transmitters were monitored with a N30A5B directional hydrophone and receiver (Dukane, St. Charles, Ill.). Buoyant radio transmitters (164-165 MHz band) were attached to one of the postcentral marginal scutes by a 0.2 -cm-diameter monofilament tether with a breakaway link (S. Morreale and E. Standora, personal communication). Tether length was approximately two-thirds the carapace length of a turtle, so that the tether would not tangle in the fore flippers and the turtle was unable to bite the transmitter. Radio transmitter floats were constructed from SH model Ecofoam $\left(128 \mathrm{~kg} / \mathrm{m}^{3}\right.$; Deanco, Winter Park, Fla.). Floats were painted grey or black to decrease detection by preda-

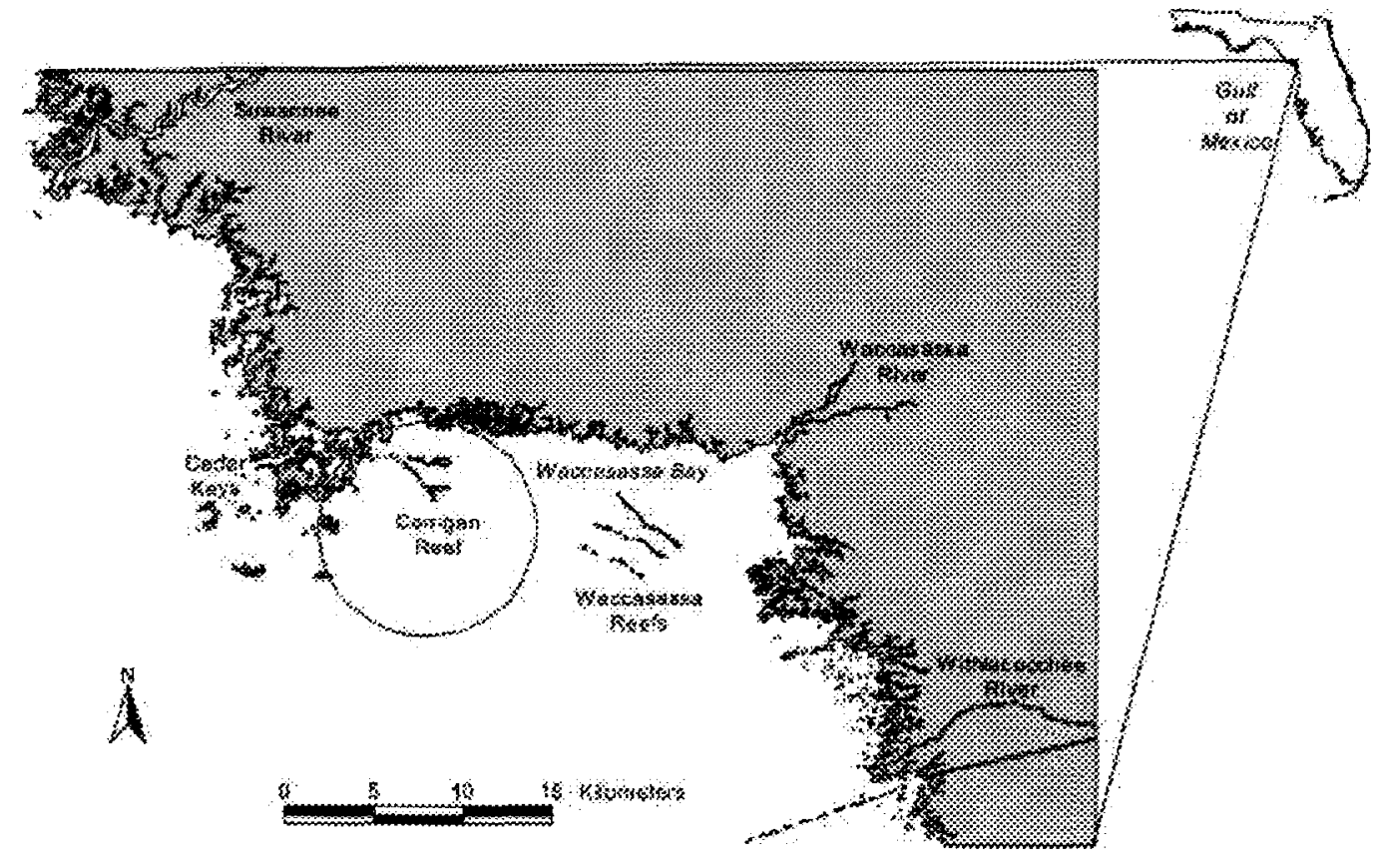


tors (i.e., sharks) and coated with an epoxy resin to reduce damage. Radio transmitters were monitored with a $\mathrm{CE} 12$ receiver (Custom Electronics of Urbana, Urbana, Ill.) connected to a directional sixelement Yagi antenna (Cushcraft, Manchester, N.H.). The radio antenna was mounted on a freely rotating mast approximately $3 \mathrm{~m}$ above the sea surface.

\section{Tracking protocol}

Radio monitoring and sonic tracking were conducted from an $8.5 \mathrm{~m}$ wooden hull vessel with an inboard engine. Telemetered turtles were released in the area of capture, and tracking began after a 24-h acclimation period. Tracking was conducted opportunistically in 1994, and most data were collected during the day. In 1995 , turtles were systematically monitored for four tracking intervals of approximately $12 \mathrm{~h}$ each, so that observations were collected each hour over two 24 -h cycles. At least $24 \mathrm{~h}$ elapsed before initiating the second tracking interval, a further $48 \mathrm{~h}$ or more elapsed before initiating the third interval, and at least $24 \mathrm{~h}$ elapsed before initiating the fourth interval. After the intensive tracking period, turtles were located opportunistically to establish their presence in the study area. Intensive tracking efforts were abandoned if a turtle traveled more than $6 \mathrm{~km}$ from South Bar Light located south of Corrigan Reef (Fig. 1).

Radio telemetry was used to monitor surface times and durations (number of pulses) of turtles and to obtain bearings for long distance tracking. Sonic telemetry was used to pinpoint the location of turtles and to track their movements. Turtle locations were re corded hourly by homing-in on the sonic signal and maneuvering the tracking vessel within 10-20 $\mathrm{m}$ of the turtle. Distances were assessed by sighting a turtle and noting the strength of the sonic signal at $1 / 2$ gain on the receiver. Turtle locations were estimated from the Universal Transverse Mercator (UTM) coordinates of the tracking vessel using a Global Positioning System (GPS, NAV 5000DX with software upgraded to NAV 5000DLX, Magellan Systems, San Dimas, Calif.) with differential correction. Accuracy of the locational estimate was approximately $5 \mathrm{~m}$ as determined from the variability associated with a fixed position. The tracking vessel was anchored in the vicinity of a telemetered turtle between acquisition of locations. Direction of tidal flow at each turtle location was determined by observation in 1994 and with a handheld compass in 1995 . Tidal flow rate was measured in 1995 by lowering a weighted flowmeter (Serial B, General Oceanics, Miami, Fla.) approximately $1 \mathrm{~m}$ below the surface and recording the number of revolutions per second within a 30 -s period. Tidal speed $(\mathrm{km} / \mathrm{h})$ was determined from the conversion chart on the flowmeter.

\section{Data analysis}

\section{Tidal orientation and rate of movement}

Relative distances in the $x(\Delta X)$ and $y(\Delta Y)$ directions were determined between consecutive locations of each turtle

$$
\Delta X=x_{i+1}-x_{i}
$$$$
\Delta Y=y_{i+1}-y_{i}
$$

where $x_{i}$ is the north UTM coordinate and $y_{i}$ is the east UTM coordinate for location $i$. The angle $\left(a_{i}\right)$ in degrees between locations was calculated as

$a_{i}= \begin{cases}\arctan (\Delta Y / \Delta X)\left(180^{\circ} / \pi\right) & \text { if } \Delta X>0 \\ 180^{\circ}+\arctan (\Delta Y / \Delta X)\left(180^{\circ} / \pi\right) & \text { if } \Delta X<0 \\ 90^{\circ} & \text { if } \Delta X=0 \text { and } \Delta Y>0 \\ 270^{\circ} & \text { if } \Delta X=0 \text { and } \Delta Y<0 .\end{cases}$

Angles were converted to bearings $\left(b_{i}\right)$ with the formula

$b_{i}=90-a_{i}$ and $360^{\circ}$ was added if the resulting value was negative (left of true north).

Directional data for each turtle were pooled respective to the tidal phase (incoming or falling) in which they occurred. Mean rectangular coordinates were computed for the pooled tidal phases of each turtle

$$
\begin{aligned}
& \bar{X}=\frac{1}{n}\left(\sum \cos a_{i}\right) \\
& \bar{Y}=\frac{1}{n}\left(\sum \sin a_{i}\right) c r
\end{aligned}
$$

Length of the mean vector $(r)$ is a measure of concentration for the sample of angles and was calculated for the pooled tidal phases of each turtle

$r=\sqrt{\bar{X}^{2}+\bar{Y}^{2}}$

When $r=0$, the mean angle $(\bar{a})$ is undefined (no concentration or multimodal angles), and when $r \neq 0, \bar{a}$ is determined by

$\bar{a}= \begin{cases}\arctan (\bar{Y} / \bar{X})\left(180^{\circ} / \pi\right) & \text { if } \bar{X}>0 \\ 180^{\circ}+\arctan (\bar{Y} / \bar{X})\left(180^{\circ} / \pi\right) & \text { if } \bar{X}<0 \\ 90^{\circ} & \text { if } \bar{X}=0 \text { and } \bar{Y}>0 \\ 270^{\circ} & \text { if } \bar{X}=0 \text { and } \bar{Y}<0 .\end{cases}$

Mean angles were converted to mean bearings $(\bar{b})$ as described for individual angles. Angular deviation ( $s$ ) was calculated with the formula

$s=180^{\circ} / \pi \sqrt{-2 \ln r}$

The computer program HOME RANGE (Ackerman et al. 1990) was used to calculate the distances traveled between consecutive locations, and rate of movement was calculated from the elapsed time between locations.

\section{Surfacing behavior}

The radio transmitters emit 50 pulses/min or one pulse every $1.2 \mathrm{~s}$. Surface duration was calculated by multiplying the recorded number of pulses by $1.2 \mathrm{~s}$. Submergence duration was estimated by the number of minutes elapsed from the beginning of the previous radio contact minus the corresponding surface duration. Rates of movement and surface/submergence durations were pooled for all turtles, by year tracked, and for each turtle by time of day (Eastern Standard Time) using the two level time intervals [0800-1959 hours (day) and 2000-0759 hours (night)] of Renaud (1995) and four level time intervals [0500-0859 hours (dawn), 0900-1659 hours (day) 1700-2059 hours (dusk), and 2100-0459 hours (night)] of Renaud et al. (1995). Surface durations, submergence durations, and number of surfacings were also pooled within the time intervals of consecutive locations for correlation analyses.

\section{Statistical methods}

A basic assumption in most statistical analyses of animal movements is the independence between successive locations collected during telemetric monitoring. Locational data collected via telemetry are considered independent if an animal's current position is not a function of its previous positions (Swihart and Slade 1985a, b; White and Garrott 1990). The time to independence has been described as the time necessary for an animal to traverse its home range (Swihart and Slade 1985a) or a statistically significant part of its home range (Ackerman et al. 1990). However, minimum time interval to statistical independence can be long enough to eliminate information of biological significance and can produce inaccurate 
estimates of daily distances traveled and activity patterns since these behaviors often require a short sample period (Andersen and Rongstad 1989; Reynolds and Laundré 1990; McNay et al. 1994) Data collection at short, systematic intervals are needed to maximize the behavioral information available from telemetry studies, despite the violation of the independence assumption (Reynolds and Laundré 1990; McNay et al. 1994; Otis and White 1999). Therefore, hourly sampling intervals were selected to quantify the behavioral trends of Kemp's ridley turtles in the Cedar Keys area despite the possibility of autocorrelated data. Efforts were made to use statistical analyses that did not require the assumption of independent observations, but this was not always possible. The computer program HOME RANGE (Ackerman et al. 1990) was used to calculate three indices of serial (auto-) correlation: $t^{2} / r^{2}$ (Swihart and Slade 1985a), $\Psi$ (psi; Swihart and Slade 1985b), and $\gamma$ (gamma; Swihart and Slade 1986). These indices were applied to 1 , 2,4 , and 6 h intervals between successive locations of each turtle to determine the minimum time to independence.

Batschelet (1981) suggested combining descriptive circular statistics for each individual to create a second-order sample of mutually independent data pairs. The mean bearings and mean vector lengths of each turtle were combined to create a second-order sample of polar coordinates for each tidal phase. The number of first-order observations for each individual must be equal for the second-order data pairs to have the same weight, although slight departures will not severely affect results. Since the tidal orientation data have unequal sample sizes, it was assumed that the data pairs for each turtle had equal weights. The $V$ test (Batschelet 1981) was used to test whether the mean bearings of the turtles were clustered around the bearings of the incoming and falling tides. Tidal bearings collected during 1995 were used to calculate mean bearings for the incoming tides and the falling tides.

Distributions of activity variables (rate of movement and surface and submergence durations) were tested with the Shapiro-Wilk test for normality. Homogeneity of variances was tested with the $F$-test for two level time intervals and Bartlett's test for homogeneity for four level time intervals. In the event of non-normality and/or nonhomogeneity of variances, the Kruskal-Wallis analysis was used to test for differences in means of the variables during a $24 \mathrm{~h}$ period. Statistical significance was accepted at $P<0.05$. When a significant difference between four level time intervals was detected and parametric assumptions had been violated, a nonparametric multiple comparison procedure described by Daniel (1990) was used to determine which means differed at $\alpha=0.05$. Although the use of the rate of movement and surface-submergence data as the sample unit to compare across animals is pseudoreplication (Otis and White 1999), these analyses were performed to describe individual variability and to compare results with previous studies. Spearman correlation coefficient was used to determine the correlations among rates of movement, mean hourly surface and submergence durations, and number of surfacings per hour for all turtles combined, by year tracked, and for each turtle. Spearman correlation coefficient was also used to determine the correlations between the body size (carapace length and mass) of each turtle and the home range area, mean rate of movement, mean number of surfacings, mean surface duration, and mean submergence duration.

\section{Results}

\section{Telemetry overview}

Five Kemp's ridley turtles were instrumented with transmitters from May to August 1994, and ten turtles were instrumented from May to November 1995. Of this total, only turtles with $>40 \mathrm{~h}$ radio monitoring or $>40$ locations were used in the analyses of activity patterns (Table 1). Turtles not included either lost their transmitters prematurely or moved out of the tracking area (Fig. 1). Carapace lengths for turtles used in the analyses ranged from 34.7 to $54.0 \mathrm{~cm}$ SCL and mass ranged from 5.9 to $23.1 \mathrm{~kg}$. The total mass of the telemetry array applied to the turtles was approximately $105 \mathrm{~g}$ (radio transmitter $\approx 58 \mathrm{~g}$, tether $\approx 11 \mathrm{~g}$, and sonic transmitter $\approx 36 \mathrm{~g}$ ), which was less than $2 \%$ of the mass of the smallest turtle (Table 1).

A minimum time to independence of $4-6 \mathrm{~h}$ was obtained by calculating the indices of autocorrelation between successive observations (Table 2). The results of this analysis should be interpreted cautiously given the reduction in sample size by deleting observations and the decreasing number of consecutive locations with increasing time intervals. The observed time to independence may correspond to the semidiurnal tide pattern (i.e., two high and two low tides a day) in the Cedar Keys area. If turtle movements were correlated with tidal flow, a turtle would traverse its home range during a 6-h tidal period. Krebs (1989) noted that ecological estimates could be biased if the sampling interval of a systematic sample corresponds with a periodic trend in environmental conditions. Sampling turtle locations at the peak high and low tides may produce a bimodal distribution of locational data, whereas sampling at midtide may yield a cluster of locations in the center of the actual home range.

Table 1 Summary of Kemp's ridley turtles, Lepidochelys kempii, used in this study

\begin{tabular}{|c|c|c|c|c|c|c|}
\hline Tag code & Turtle ID & $\begin{array}{l}\text { Carapace length } \\
(\mathrm{cm})\end{array}$ & Mass (kg) & Contact duration & $\begin{array}{l}\text { Hours monitored } \\
\text { (radio) }\end{array}$ & $\begin{array}{l}\text { Number of } \\
\text { locations (sonic) }\end{array}$ \\
\hline \multicolumn{7}{|l|}{1994 season } \\
\hline PPY $168-169^{a}$ & LK 1 & 43.4 & 11.8 & $5 / 30-7 / 15$ & 48.8 & 69 \\
\hline PPY 172-173 & LK2 & 54.0 & 23.1 & $6 / 19-7 / 01$ & 43.8 & 47 \\
\hline PPY $175-176$ & LK3 & 46.2 & 14.1 & $7 / 09-7 / 26$ & 16.2 & 50 \\
\hline PPY $177-178$ & LK4 & 36.6 & 7.7 & $8 / 01-8 / 27$ & 59.1 & 53 \\
\hline \multicolumn{7}{|l|}{1995 season } \\
\hline PPY 183-184 & LK5 & 41.9 & 11.3 & $5 / 04-6 / 15$ & 16.5 & 57 \\
\hline PPY 185-186 & LK6 & 46.0 & 13.4 & $5 / 22-7 / 27$ & 58.8 & 65 \\
\hline PPY 191-192 & LK 7 & 49.9 & 19.0 & $6 / 19-7 / 24$ & 55.8 & 59 \\
\hline PPY 195-196 & LK 8 & 34.7 & 5.9 & $7 / 14-9 / 22$ & 54.2 & 58 \\
\hline PPY 197-198 & LK9 & 49.3 & 16.3 & $8 / 05-8 / 19$ & 51.2 & 54 \\
\hline
\end{tabular}

${ }^{a}$ Originally tagged 3 October 1991, recaptured 20 September 1992, and recaptured 2 May 1994

${ }^{b}$ Originally tagged 1991 (marginal mark), recaptured 19 September 1993, and recaptured 5 August 1995 
Tidal orientation

The mean of mean turtle bearings was $48 \pm 49^{\circ}$ for incoming tides and $232 \pm 41^{\circ}$ for falling tides (Table 3). The mean tidal bearings for 1995 were $37 \pm 9^{\circ}(r=0.9879$, $n=113)$ for incoming tides and $234 \pm 9^{\circ}(r=0.9867$, $n=149$ ) for falling tides. The second-order samples of turtle bearings differed significantly from randomness for both the incoming tides $(u=2.90,0.001<P<0.0025)$ and the falling tides $(u=3.30, P<0.005)$, indicating that the mean bearings of turtles were clustered around the mean bearings of the tidal states (Fig. 2).

Mean vector lengths were low for incoming tides (Table 3) and mean angular deviations ranged from $69^{\circ}$
Table 2 Indices of serial correlation for determining the time to independence of Kemp's ridley turtle locational data

\begin{tabular}{|c|c|c|c|c|}
\hline \multirow[t]{2}{*}{ Turtle ID } & \multirow{2}{*}{$\begin{array}{l}\text { Hourly } \\
\text { interval }\end{array}$} & \multicolumn{3}{|c|}{ Indices of serial correlation } \\
\hline & & $t^{2} / r^{2}$ & $\psi$ & $\gamma$ \\
\hline \multirow[t]{4}{*}{ LK1 } & 1 & $0.34^{*}$ & $2.59 *$ & $0.83^{*}$ \\
\hline & 2 & $0.69^{*}$ & $2.10^{*}$ & $0.65^{*}$ \\
\hline & 4 & $1.13^{*}$ & $1.52^{*}$ & 0.35 n.s. \\
\hline & 6 & $1.19^{*}$ & $1.09^{*}$ & 0.27 n.s. \\
\hline \multirow[t]{4}{*}{ LK2 } & 1 & $0.41^{*}$ & $2.25^{*}$ & $0.77^{*}$ \\
\hline & 2 & $0.75^{*}$ & $1.79 *$ & $0.58^{*}$ \\
\hline & 4 & $0.67^{*}$ & $1.91^{*}$ & $0.49^{*}$ \\
\hline & 6 & $1.28^{*}$ & $1.13^{*}$ & 0.16 n.s. \\
\hline \multirow[t]{4}{*}{ LK3 } & 1 & $0.23^{*}$ & $2.48^{*}$ & $0.85^{*}$ \\
\hline & 2 & $0.48^{*}$ & $1.91^{*}$ & $0.67^{*}$ \\
\hline & 4 & $0.94^{*}$ & $1.20^{*}$ & $0.34^{*}$ \\
\hline & 6 & $1.45^{*}$ & $0.66 \mathrm{n} . \mathrm{s}$ & 0.08 n.s. \\
\hline \multirow[t]{4}{*}{ LK4 } & 1 & $0.40^{*}$ & $1.71^{*}$ & $0.78 *$ \\
\hline & 2 & $0.82^{*}$ & $1.15^{*}$ & $0.56^{*}$ \\
\hline & 4 & $1.36^{*}$ & $0.69^{*}$ & 0.18 n.s. \\
\hline & 6 & $1.58 *$ & 0.07 n.s. & -0.04 n.s. \\
\hline \multirow[t]{4}{*}{ LK5 } & 1 & $0.26^{*}$ & $2.26^{*}$ & $0.85^{*}$ \\
\hline & 2 & $0.55^{*}$ & $1.95^{*}$ & $0.70^{*}$ \\
\hline & 4 & $1.04^{*}$ & $1.55^{*}$ & $0.44^{*}$ \\
\hline & 6 & 1.77 n.s. & $0.80^{*}$ & 0.05 n.s. \\
\hline \multirow[t]{4}{*}{ LK6 } & 1 & $0.22^{*}$ & $2.42^{*}$ & $0.84^{*}$ \\
\hline & 2 & $0.46^{*}$ & $1.98^{*}$ & $0.66^{*}$ \\
\hline & 4 & $0.86^{*}$ & $0.97^{*}$ & $0.31^{*}$ \\
\hline & 6 & $1.26^{*}$ & 0.45 n.s. & 0.13 n.s. \\
\hline \multirow[t]{4}{*}{ LK7 } & 1 & $0.32 *$ & $2.55^{*}$ & $0.84^{*}$ \\
\hline & 2 & $0.63^{*}$ & $2.21^{*}$ & $0.68^{*}$ \\
\hline & 4 & $1.23^{*}$ & $1.36^{*}$ & $0.37^{*}$ \\
\hline & 6 & $1.54^{*}$ & $0.87^{*}$ & 0.21 n.s. \\
\hline \multirow[t]{4}{*}{ LK8 } & 1 & $0.16^{*}$ & $2.29 *$ & $0.90^{*}$ \\
\hline & 2 & $0.29^{*}$ & $1.93^{*}$ & $0.79^{*}$ \\
\hline & 4 & $0.64^{*}$ & $1.20^{*}$ & $0.51^{*}$ \\
\hline & 6 & $1.08^{*}$ & $0.85^{*}$ & 0.21 n.s. \\
\hline \multirow[t]{4}{*}{ LK9 } & 1 & $0.17^{*}$ & $3.02^{*}$ & $0.87^{*}$ \\
\hline & 2 & $0.42^{*}$ & $2.60^{*}$ & $0.70^{*}$ \\
\hline & 4 & $0.92^{*}$ & $1.47^{*}$ & $0.41 *$ \\
\hline & 6 & $0.97^{*}$ & $1.33^{*}$ & $0.34^{*}$ \\
\hline
\end{tabular}

*Significant $(P<0.05)$ autocorrelation, n.s. no significant autocorrelation

Table 3 Mean bearings and vector lengths for telemetered Kemp's ridley turtles during falling and incoming tides. Mean angular deviations given in parentheses

\begin{tabular}{lllllll}
\hline Turtle ID & $\begin{array}{l}\text { Mean bearing } \\
\text { incoming tide }\end{array}$ & No. of fixes & $\begin{array}{l}\text { Mean vector } \\
\text { length }\end{array}$ & $\begin{array}{l}\text { Mean bearing } \\
\text { falling tide }\end{array}$ & No. of fixes & $\begin{array}{l}\text { Mean vector } \\
\text { length }\end{array}$ \\
\hline LK1 & $29(134)$ & 29 & 0.0639 & $119(114)$ & 24 & 0.1361 \\
LK2 & $174(131)$ & 22 & 0.0724 & $271(81)$ & 13 & 0.3706 \\
LK3 & $345(90)$ & 19 & 0.2885 & $249(47)$ & 22 & 0.7142 \\
LK4 & $37(69)$ & 11 & 0.4881 & $238(66)$ & 31 & 0.5123 \\
LK5 & $67(92)$ & 19 & 0.2790 & $265(77)$ & 30 & 0.4060 \\
LK6 & $48(85)$ & 26 & 0.3308 & $238(82)$ & 33 & 0.3578 \\
LK7 & $70(86)$ & 25 & 0.3245 & $229(56)$ & 29 & 0.6204 \\
LK8 & $8(75)$ & 20 & 0.4268 & $199(103)$ & 28 & 0.1979 \\
LK9 & $82(123)$ & & 0.1004 & $225(103)$ & 29 & 0.1963 \\
Second-order & $48(49)$ & 0.6947 & $232(41)$ & & 0.7772 \\
statistics & & & & & & \\
\hline
\end{tabular}


Fig. 2 Mean bearings and vector lengths by tide state for Kemp's ridley turtles, Lepidochelys kempii. Radial axis is mean vector length $(r)$. Black arrows indicate the mean of mean bearings and vector lengths for turtles and white arrows indicate mean tidal bearings for 1995

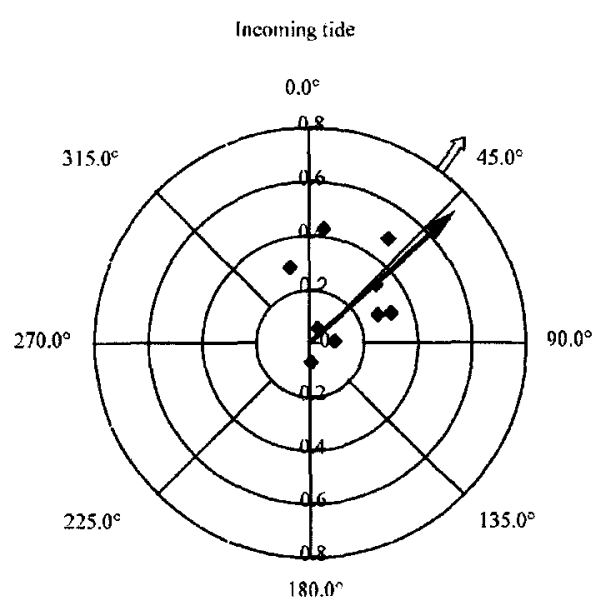

A Incoming Tides

Hourly bearings and distances traveled by tide state for Kemp's ridley turtles. Radial axis is distance traveled (m). Black arrows indicate the mean bearings for turtles and white arrows indicate mean tidal bearings for 1995
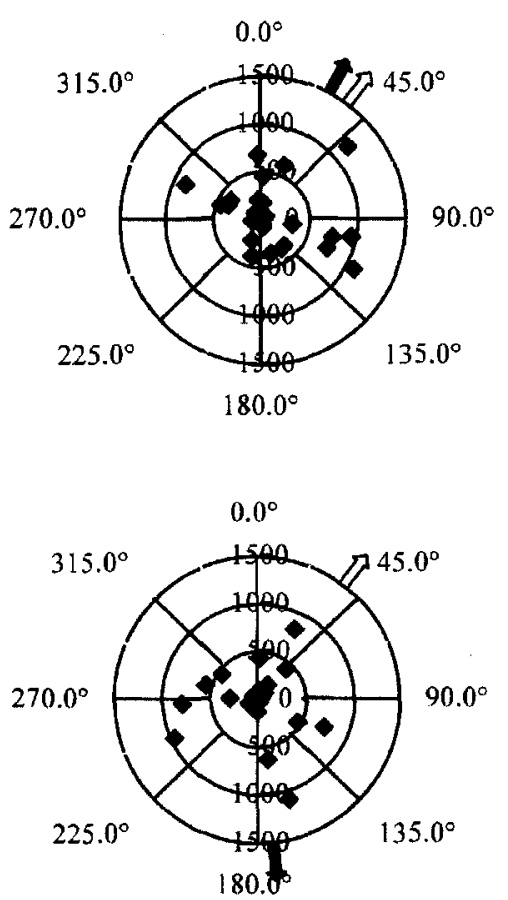

LK2

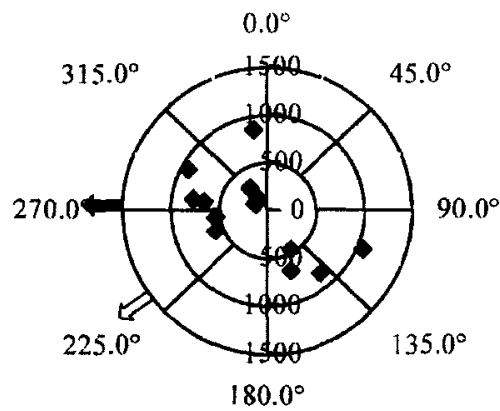

LK3

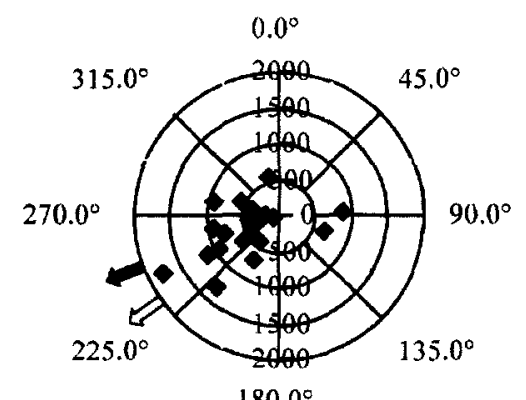

$180.0^{\circ}$

to $134^{\circ}$. Mean vector lengths for falling tides were rel- to $114^{\circ}$. The two datasets with the smallest sample sizes atively higher, indicating an increased concentration of (LK2, falling tide and LK4, incoming tide) exhibited bearings, and mean angular deviations ranged from $56^{\circ}$ intermediate mean vector lengths, although that of LK4 
was also the highest for incoming tides. The distribution of bearings and hourly distances by tide state (Fig. 3) indicated three patterns of orientation: undirected movements less than $500 \mathrm{~m}$ (LK6 - incoming and LK9 incoming), movements perpendicular to the direction of tidal flow (LK1 - falling and LK8 - falling), and movements corresponding to the direction of the tide (LK3 - falling and LK 7 - falling). The first two patterns resulted in decreased mean vector lengths and increased angular deviations.

\section{Rate of movement}

The mean rate of movement (ROM) for all turtles combined was $0.437 \pm 0.331 \mathrm{~km} / \mathrm{h}$ (range: 0.004 $1.758 \mathrm{~km} / \mathrm{h}$ ). There was a significant difference $\left(\chi^{2}=34.31, P=0.0001\right)$ among the ROM of individual turtles. LK3 had the highest mean ROM (Table 4), which was significantly greater than those of LK1, LK8, and LK9. LK3 had the highest recorded ROM, and $18.3 \%$ of the observations for LK3 were greater than $1 \mathrm{~km} / \mathrm{h}$. Conversely, LK 8 had the lowest mean ROM (Table 4), which was significantly lower than the rates of all turtles except LK1 and LK9. LK8 was the smallest turtle tracked in this study (Table 1), but mean ROM of turtles was not significantly correlated with carapace length or mass (Spearman correlation coefficient $=0.57$, $P=0.11$ ).

Mean ROM was significantly greater on the falling tide (Table 5) for all Kemp's ridley turtles combined $\left(\chi^{2}=7.11, P=0.008\right)$ and turtles tracked in $1995\left(\chi^{2}=\right.$ 4.11, $P=0.04)$, but was not significantly different for turtles tracked in $1994\left(\chi^{2}=3.19, P=0.07\right)$. Mean ROM of individual turtles differed significantly by tidal state (falling tide: $\chi^{2}=28.02, P=0.0005$; incoming tide: $\left.\chi^{2}=16.13, P=0.041\right)$. The tide flow data collected in 1995 indicated a trend for higher mean tidal velocities on
Fig. 3 (Contd.)
B Incoming Tides
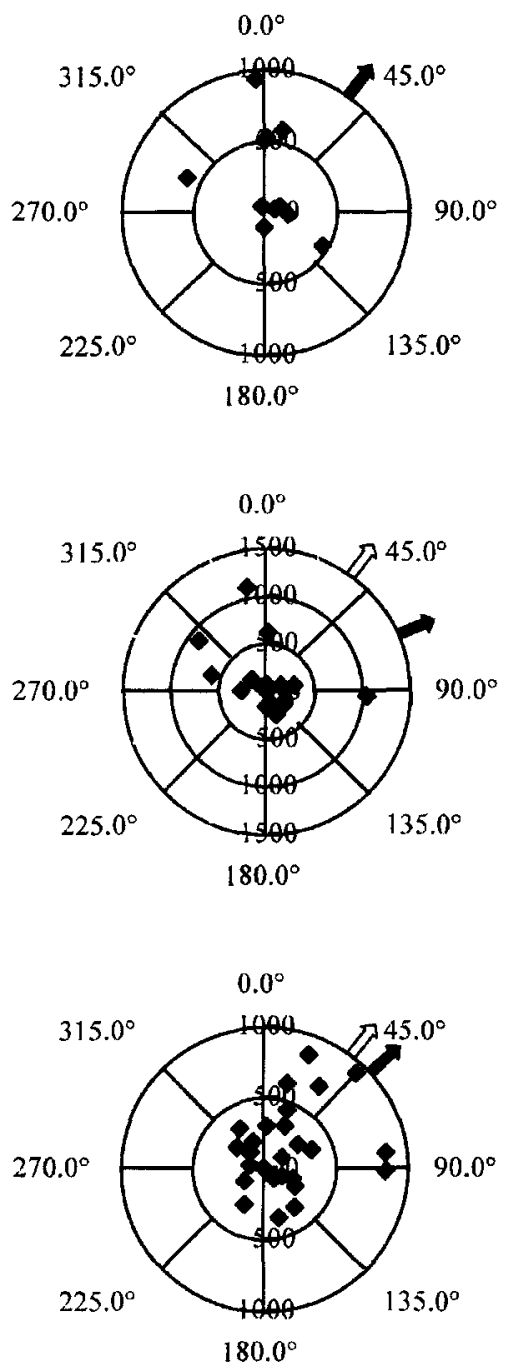

LK4

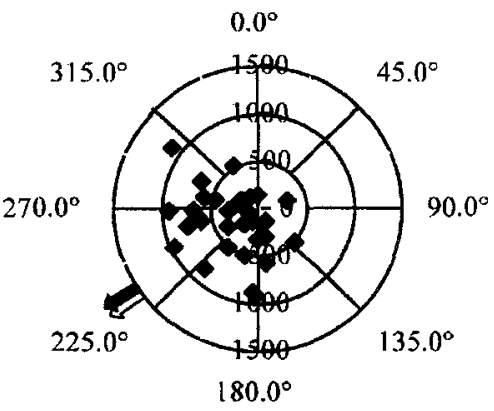

LKS

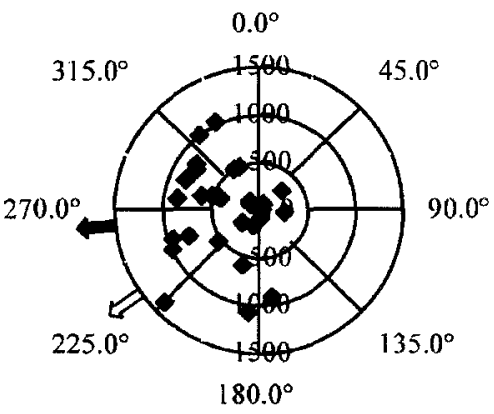

LK6

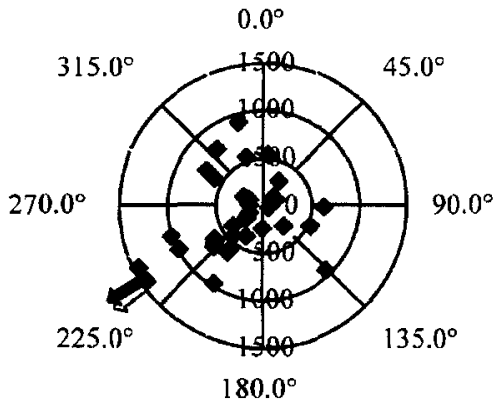


Fig. 3 (Contd.)
Fall ing Tides
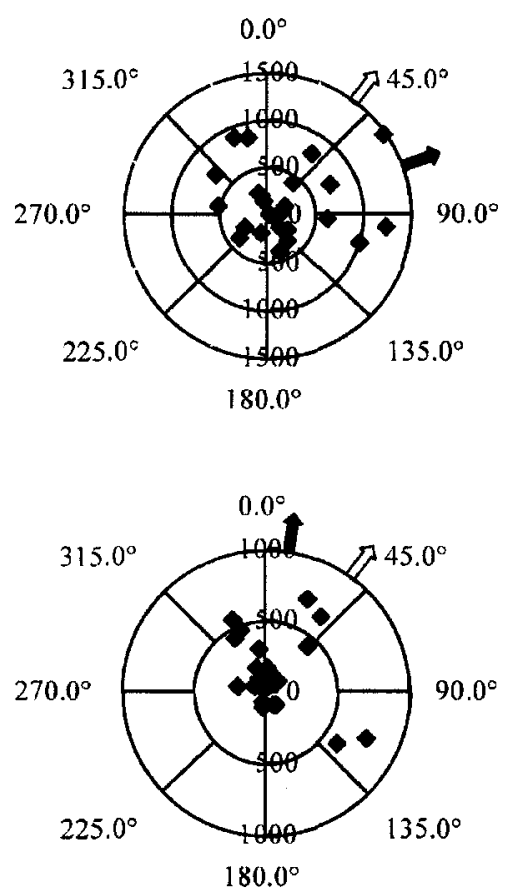

LK8

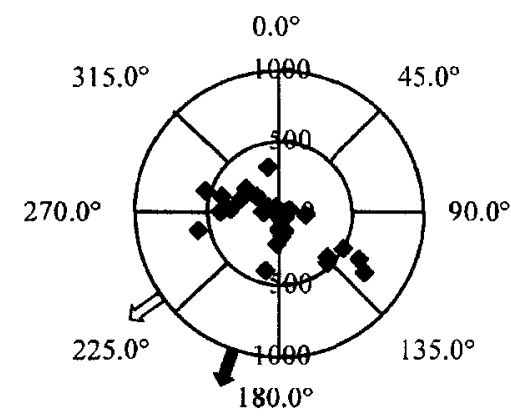

LK9

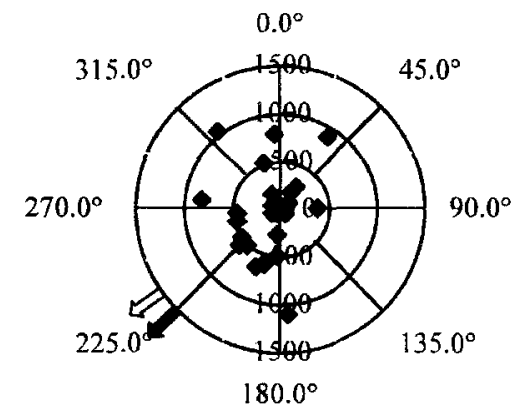

Table 4 Mean rate of movement and percent composition of movement rates for Kemp's ridley turtles. Standard deviations are given in parentheses. Means that share the same superscript are not significantly different using the nonparametric multiple comparison procedure

\begin{tabular}{|c|c|c|c|c|c|}
\hline \multirow[t]{2}{*}{ Turtle ID } & \multirow[t]{2}{*}{ Mean rate of movement } & \multicolumn{4}{|c|}{ Rate of movement $(\mathrm{km} / \mathrm{h})$} \\
\hline & & $<0.5$ & $0.5-1.0$ & $1.0-1.5$ & $>1.5$ \\
\hline $\begin{array}{l}\text { LK1 } \\
\text { LK2 } \\
\text { LK3 } \\
\text { LK4 } \\
\text { LK5 } \\
\text { LK6 } \\
\text { LK7 } \\
\text { LK8 } \\
\text { LK9 }\end{array}$ & $\begin{array}{l}0.391^{\mathrm{a}, \mathrm{d}}(0.308) \\
0.487^{\mathrm{a}, \mathrm{b}}(0.324) \\
0.600^{\mathrm{b}}(0.407) \\
0.441^{\mathrm{a}, \mathrm{b}, \mathrm{c}}(0.282) \\
0.478^{\mathrm{a}, \mathrm{b}}(0.366) \\
0.474^{\mathrm{a}, \mathrm{b}}(0.326) \\
0.524^{\mathrm{b}}(0.329) \\
0.274^{\mathrm{d}}(0.210) \\
0.338^{\mathrm{c}, \mathrm{d}}(0.282)\end{array}$ & $\begin{array}{l}66.1 \\
53.7 \\
47.7 \\
56.8 \\
58.0 \\
57.6 \\
50.0 \\
84.9 \\
71.4\end{array}$ & $\begin{array}{l}30.5 \\
41.5 \\
34.1 \\
40.9 \\
32.0 \\
37.3 \\
38.9 \\
15.1 \\
28.6\end{array}$ & $\begin{array}{r}3.4 \\
4.9 \\
13.7 \\
2.3 \\
10.0 \\
5.1 \\
11.1 \\
0.0 \\
0.0\end{array}$ & $\begin{array}{l}0.0 \\
0.0 \\
4.6 \\
0.0 \\
0.0 \\
0.0 \\
0.0 \\
0.0 \\
0.0\end{array}$ \\
\hline
\end{tabular}

the incoming tides (Table 5), but the difference between tidal states was not significant. For the combined data of 1995 , there was a significant positive correlation between tidal speeds and turtle ROM on both falling (Spearman corr. coeff. $=0.196, \quad P=0.02)$ and incoming tides (Spearman correlation coefficient $=0.232, P=0.01$ ). 


\section{Surfacing behavior}

Field observations indicated that Kemp's ridley turtles exhibited surface durations of 1-2 s and submergence durations of 1-2 min upon release and continuing for several hours. This pattern was probably in response to the stress of capture and handling, and these data were therefore not included in behavioral analyses. Telemetered turtles exhibited longer surface and submergence durations after the 24-h acclimation period. Presumably, a 24-h period of recovery was adequate because this type of surfacing pattern continued through the remainder of the monitoring sessions.

The mean surface duration for all turtles combined was $18 \pm 15 \mathrm{~s}$ (range: $1-88 \mathrm{~s}$ ) and the mean submergence duration was $8.4 \pm 6.4 \mathrm{~min}$ (range: $0.2-60.0 \mathrm{~min}$ ). However, there were significant differences in the mean surface durations $\left(\chi^{2}=368.5, P=0.0001\right)$ and submergence durations $\left(\chi^{2}=375.1, \quad P=0.0001\right)$ among individual turtles (Table 6). The mean surface and submergence durations for LK6 and LK 7 were significantly less than those of the other turtles, and $58 \%$ of the surface durations for these two turtles were less than $10 \mathrm{~s}$ (Fig. 4). Furthermore, LK6 and LK 7 also exhibited significantly higher mean numbers of surfacings per hour (Table 6). Both of these turtles had injuries to their rear flippers, though LK1 had the same type of wounds and did not display a similar surfacing pattern.

Telemetered Kemp's ridley turtles spent 95.7-97.0\% of their time submerged (Table 6). Despite the increased frequency of surfacings and shorter surfacing durations, LK 7 exhibited the longest surface duration ( $88 \mathrm{~s})$ used in the analyses. However, surface durations of 4-8 min were recorded for two of the turtles not included in these analyses owing to insufficient data. The longer surface durations recorded for these turtles may be indicative of basking behavior. Non-telemetered Kemp's ridley turtles were observed floating on the surface for extended periods of time, and one such turtle appeared to be resting (motionless with foreflippers tucked laterally) within seagrass flotsam (video clip, see electronic supplementary material).

There were significant correlations between ROM, number of surfacings, and surface and submergence durations for the combined data of all turtles and turtles tracked in 1995, though number of surfacings and submergence duration were not correlated to ROM for turtles tracked in 1994 (Table 7). Increased ROMs corresponded to increased number of surfacings and decreased surface and submergence durations. The number of surfacings decreased with increasing surface and submergence durations, and increased surface durations corresponded to increased submergence durations.

There were trends for decreasing number of surfacings and surface durations and increasing submergence durations with both increasing carapace length and mass (body size), but the correlations between these variables were not significant. If the data of LK6 and LK7 were omitted because of their significantly different surfacing pattern there were significant positive correlations (Spearman correlation coefficient $=0.9, P=0.04$ ) between mean submergence duration and body size, and significant negative correlations (Spearman correlation coefficient $=-0.9, P=0.04$ ) between mean number of surfacings and body size. The largest turtle (LK2; $54.0 \mathrm{~cm} \mathrm{SCL}$ ) exhibited the longest submergence duration $(59 \mathrm{~min})$. However, submergence durations of 71 $84 \mathrm{~min}$ were recorded for a smaller turtle $(36.8 \mathrm{~cm} \mathrm{SCL})$ not included in these analyses owing to insufficient data. This smaller turtle was monitored later in the year (late October and early November) than any of the other turtles, during a period when water temperature

Table 5 Mean rate of movement $(\mathrm{km} / \mathrm{h})$ for Kemp's ridley turtles and mean tidal speed $(\mathrm{km} / \mathrm{h})$ by tidal state. < indicates a significant difference between tidal states using the Kruskal-Wallis test

\begin{tabular}{|c|c|c|c|c|}
\hline \multirow[b]{2}{*}{ Turtle ID } & \multicolumn{2}{|c|}{ Mean rate of movement } & \multicolumn{2}{|c|}{ Mean tidal speed } \\
\hline & Incoming tide & Falling tide & Incoming tide & Falling tide \\
\hline $\begin{array}{l}\text { All turtles combined } \\
1994 \text { turtles } \\
1995 \text { turtles }\end{array}$ & $\begin{array}{l}0.394 \\
0.424 \\
0.371\end{array}$ & $\begin{array}{l}<0.476 \\
-0.509 \\
<0.456\end{array}$ & 0.508 & -0.413 \\
\hline
\end{tabular}

Table 6 Summary of the surface and submergence durations for telemetered Kemp's ridley turtles. Standard deviations are given in parentheses. Means that share the same superscript are not significantly different using the nonparametric multiple comparison procedure

\begin{tabular}{llll}
\hline Turtle ID & $\begin{array}{l}\text { Mean number } \\
\text { of surfacings per hour }\end{array}$ & $\begin{array}{l}\text { Mean surface } \\
\text { duration (s) }\end{array}$ & $\begin{array}{l}\text { Mean submergence } \\
\text { duration (min) }\end{array}$ \\
\hline LK1 & $5.6^{\mathrm{a}, \mathrm{c}}(1.5)$ & $22.8^{\mathrm{a}}(15.1)$ & $10.68^{\mathrm{a}, \mathrm{b}}(6.45)$ \\
LK2 & $4.9^{\mathrm{a}, \mathrm{c}}(1.9)$ & $17.7^{\mathrm{c}}(13.7)$ & $12.15^{\mathrm{a}}(8.86)$ \\
LK4 & $6.3^{\mathrm{a}}(3.1)$ & $23.9^{\mathrm{a}, \mathrm{b}}(15.2)$ & $9.05^{\mathrm{c}}(5.67)$ \\
LK6 & $9.6^{\mathrm{b}}(4.1)$ & $11.1^{\mathrm{d}}(8.8)$ & $5.95^{\mathrm{d}}(5.56)$ \\
LK7 & $9.8^{\mathrm{b}}(4.2)$ & $14.8^{\mathrm{e}}(13.6)$ & $5.90^{\mathrm{d}}(4.48)$ \\
LK8 & $5.9^{\mathrm{a}, \mathrm{c}}(2.9)$ & $22.3^{\mathrm{a}}(14.8)$ & $9.74^{\mathrm{b}, \mathrm{c}}(5.97)$ \\
LK9 & $5.0^{\mathrm{c}}(2.1)$ & $25.9^{\mathrm{b}}(16.2)$ & $11.32^{\mathrm{a}}(6.28)$ \\
\hline
\end{tabular}


typically decreases (Schmid 1998). In fact, the longer submergence durations of this smaller turtle were recorded after the passage of a cold front, indicating that the surfacing behavior of Kemp's ridley turtles is also correlated with seasonal changes in environmental conditions.

\section{Diel activity patterns}

Only Kemp's ridley turtles tracked in 1995 had sufficient 24-h data to test for time interval patterns of ROM. There was a trend for higher mean ROM during the day, but there were no significant differences between two level intervals and among four level intervals (Table 8).

Mean surface durations were not significantly different during the two 12-h time intervals for all turtles combined (Table 8). However, the data for each year indicated a significantly longer mean surface duration during the 12-h day for turtles tracked in 1994 and during the 12-h night for turtles tracked in 1995. This discrepancy may have resulted from sampling error as 1994 turtles were not systematically monitored for a full 24-h period. The mean surface duration during the $8-h$ night was significantly longer than the 4-h dusk and dawn for all turtles combined, and was significantly longer than the other four level intervals for turtles tracked in 1995 (Table 8).

Mean submergence durations were significantly longer during the 12-h night for the combined data of all turtles and turtles tracked during each year (Table 8). For all turtles combined, the mean submergence duration during the 8 -h night was significantly longer than those during the $8-\mathrm{h}$ day and $4-\mathrm{h}$ dusk, and the mean submergence duration during the 4 -h dawn was significantly longer than that of the 4-h dusk. For turtles tracked in 1995, the mean submergence durations during the 8-h night and 4-h dawn were significantly longer than those during the 8-h day and 4-h dusk.

\section{Discussion}

In contrast to Byles' (1988) observations in Chesapeake Bay, the Kemp's ridley turtles in the present study

Table 7 Spearman correlation analyses of the rate of movement $(\mathrm{km} / \mathrm{h})$, number of surfacings per hour, and mean hourly surface and submergence durations for Kemp's ridley turtles. Number of
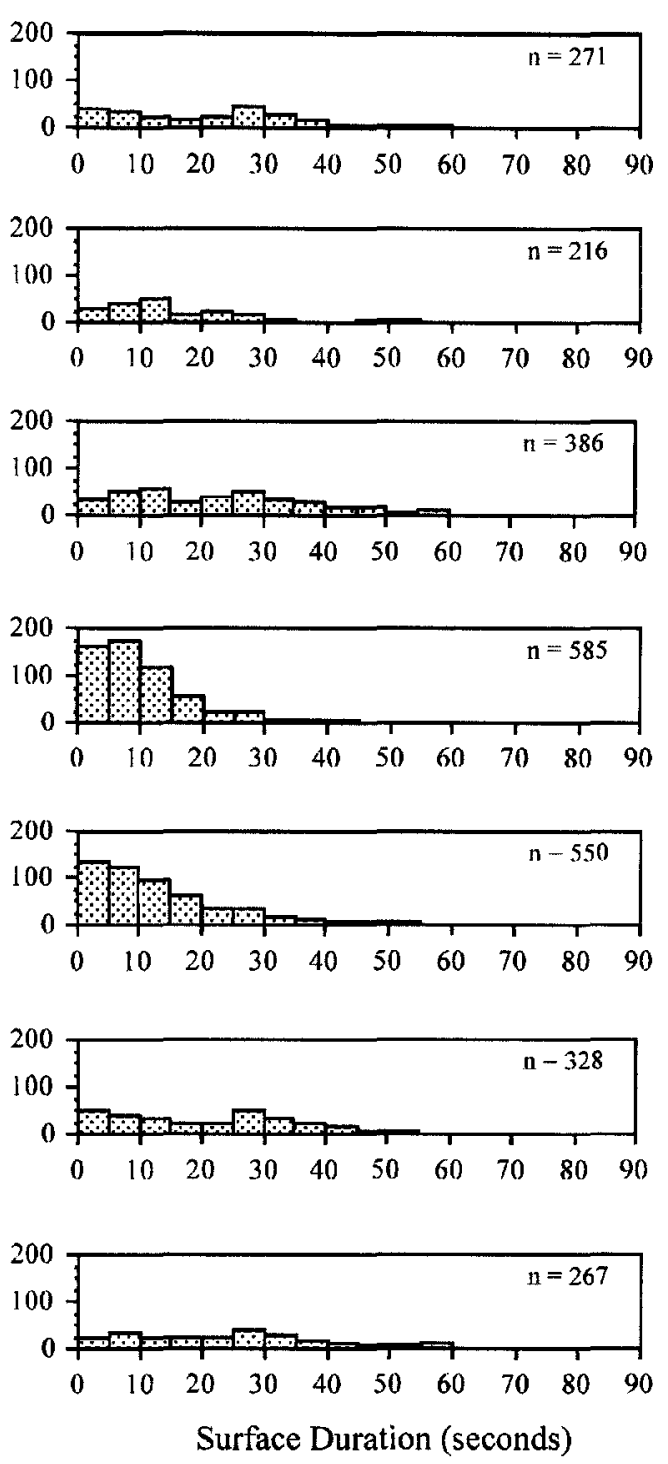

Fig. 4 Frequency distributions of surfacing duration (10-s intervals) for Kemp's ridley turtles. Numbers indicate total number of surfacings

oriented their movements with the direction of the prevailing tide, and increased their rate of movement with the tide with increasing tidal velocity. The differ-

surfacings and surface/submergence durations were pooled within the time intervals of consecutive locations. $P$-values are in parentheses and significant correlations are in bold

\begin{tabular}{|c|c|c|c|c|}
\hline \multicolumn{2}{|l|}{ Data treatment } & $\frac{\text { Rate of movement }}{0.3081(0.0001)}$ & No. of surfacings & \multirow[t]{2}{*}{ Surface duration } \\
\hline All turtles combined & $\begin{array}{l}\text { No. of surfacings } \\
\text { Surface duration } \\
\text { Submergence duration }\end{array}$ & $\begin{array}{r}0.3081(0.0001) \\
-0.2911(0.0001) \\
-0.2911(0.0001)\end{array}$ & $\begin{array}{l}-0.6704(0.0001) \\
-0.9588\end{array}$ & \\
\hline 1994 turtles & $\begin{array}{l}\text { No. of surfacings } \\
\text { Surface duration } \\
\text { Submergence duration }\end{array}$ & $\begin{array}{r}0.1438(0.1155) \\
-0.2809(0.0018) \\
-0.1655(0.0697)\end{array}$ & $\begin{array}{l}-0.3523(0.0001) \\
-0.9197(0.0001)\end{array}$ & $0.3329(0.0002)$ \\
\hline 1995 turtles & $\begin{array}{l}\text { No. of surfacings } \\
\text { Surface duration } \\
\text { Submergence duration }\end{array}$ & $\begin{array}{r}0.4270(0.0001) \\
-0.3145(0.0001) \\
-0.3963(0.0001)\end{array}$ & $\begin{array}{l}-0.8079(0.0001) \\
-0.9735(0.0001)\end{array}$ & $0.8088(0.0001)$ \\
\hline
\end{tabular}


ence in behavior between studies may represent acclimatization by the turtles to regional differences in tidal conditions. Tidal currents in the Cedar Keys area are relatively strong, especially in the channels that cut through the flats and shoals. As pointed out by Byles (1988), movement with or perpendicular to the tidal flow would be energetically beneficial to a turtle. Comparatively, the tidal flow on the shallow seagrass beds of Chesapeake Bay may not be as strong, resulting in movements by Kemp's ridley turtles that appear to be non-directed. Despite significant tidal orientation, Kemp's ridley turtles in the Cedar Keys also exhibited extended $(>2 \mathrm{~h}$ ) periods of little or no directed movement regardless of the tidal state. During daylight hours, telemetered turtles were observed surfacing toward the direction of tidal flow when remaining relatively stationary. Apparently, the turtles were swimming against the tidal current while ascending and descending to maintain a fixed position. Since turtles were not observed underwater, it is not known whether these stationary periods represent resting at a specific site on the bottom or active foraging within a confined area. Resting and maintaining a fixed location against the tide would be energetically disadvantageous, so if turtles are optimizing their swimming energetics, it is likely that turtles are foraging during these stationary periods.

There is little information available on the rate of movement of Kemp's ridley turtles. Renaud (1995) reported an overall mean swimming velocity of $1.0 \mathrm{~km} /$ $\mathrm{h}$, with individual mean velocities of $0.7-11.0 \mathrm{~km} / \mathrm{h}$. Gitschlag (1996) recorded a mean rate of movement of $0.82 \mathrm{~km} / \mathrm{h}$ for an adult-sized female on the Atlantic coast. In the present study, the mean rate of movement for Kemp's ridley turtles was $0.44 \mathrm{~km} / \mathrm{h}$ with individual mean rates of $0.27-0.60 \mathrm{~km} / \mathrm{h}$. The values reported by each study appear consistent with the activities of the turtles. With the exception of a single turtle in the Gulf, Renaud (1995) tracked Kemp's ridley turtles migrating along the Atlantic coast during fall and winter, when higher rates of movement would be expected. Gitschlag (1996) tracked two other turtles that

Table 8 Mean rate of movement $(\mathrm{km} / \mathrm{h})$, mean surface duration (nearest s), and mean submergence duration (nearest s) for Kemp's ridley turtles by time of day ( $W$ dawn, $D$ day, $K$ dusk, and $N$ night) $<$ indicates a significant difference between time intervals using the also had high rates of movement during their southerly migration, though the mean values were not reported. The Kemp's ridley turtles tracked in the present study were utilizing summer foraging grounds, when lower rates of movement would be expected, although their rates of movement are likely to increase when they depart from the nearshore waters of the Cedar Keys during the fall.

Radio and satellite transmitters have been used to investigate the surfacing behavior of Kemp's ridley turtles, but comparisons among studies are confounded by differences between the telemetric methodologies. The data obtained from satellite transmitters are in terms of submergence patterns and are summarized in 12-h intervals, whereas the data obtained from radio transmitters are in terms of surfacing patterns and are collected consecutively. Nonetheless, surface durations can be compared among studies using radio telemetry, and overall submergence behavior can be compared among all studies. The mean surface duration for subadult turtles in the present study is slightly less than that of inter-nesting females, but is 4 and 7 times less than the durations reported for subadults on the Atlantic coast (Table 9). Differences in the attachment of the radio transmitter and the activities of the turtles may explain the discrepancy. Byles (1988) used $1 \mathrm{~m}$ lanyards, compared to the approximately $25-36 \mathrm{~cm}$ tether lengths used herein, which could have resulted in longer surface duration of the radio transmitters. The turtles tracked by Gitschlag (1996) were actively migrating southward, and the longer surface durations he recorded may have been the result of their travelling in relatively deeper and cooler waters. Despite similarities in percent time submerged, the mean submergence duration in the present study was shorter than that reported by any other investigator (Table 9). The shallow water depths in the Cedar Keys study area may explain the shorter submergence durations, though other differences between studies (type and attachment of transmitter, temperature of water, and developmental stage and activities of turtles) may have been contributing factors.

Kruskal-Wallis test for two levels and the nonparametric multiple comparison procedure for four levels. Parentheses were used to consolidate significant differences

\begin{tabular}{lll}
\hline Activity and data treatment & Time of day & \\
\cline { 2 - 3 } & Two level intervals & Four level intervals \\
\hline $\begin{array}{l}\text { Rate of movement } \\
1995 \text { turtles }\end{array}$ & $\mathrm{D} 0.464-\mathrm{N} 0.374$ & $\mathrm{D} 0.508-\mathrm{K} 0.390-\mathrm{N} 0.377-\mathrm{W} 0.353$ \\
$\begin{array}{l}\text { Surface duration } \\
\text { All turtles }\end{array}$ & $\mathrm{N} 19-\mathrm{D} 18$ & $\mathrm{~N} 20>\mathrm{W} 17-\mathrm{K} 17)-\mathrm{D} 19$ \\
1994 turtles & $\mathrm{D} 23>\mathrm{N} 19$ & $\mathrm{D} 19-\mathrm{W} 17-\mathrm{K} 16-\mathrm{N} 14$ \\
1995 turtles & $\mathrm{N} 18>\mathrm{D} 15$ & $\mathrm{~N} 17>\mathrm{D} 14-\mathrm{W} 13-\mathrm{K} 12$ \\
$\begin{array}{l}\text { Submergence duration } \\
\text { All turtles }\end{array}$ & $\mathrm{N} 523>\mathrm{D} 494$ & $\mathrm{~N} 545>\mathrm{D} 497-\mathrm{K} 468$ and W520 $>$ K468 \\
1994 turtles & $\mathrm{N} 652>\mathrm{D} 609$ & W649-K642-N639-D596 \\
1995 turtles & $\mathrm{N} 491>\mathrm{D} 410$ & $\mathrm{~N} 521-\mathrm{W} 476>\mathrm{D} 404-\mathrm{K} 394$ \\
\hline
\end{tabular}


Table 9 Lepidochelys kempii. Published sources of surface and submergence durations for Kemp's ridley turtles. Parentheses indicate extrapolated values

\begin{tabular}{|c|c|c|c|c|c|}
\hline $\begin{array}{l}\text { Transmitter/ } \\
\text { attachment }\end{array}$ & Life history stage ${ }^{a}$ & Sample size & $\begin{array}{l}\text { Mean surface } \\
\text { duration (s) }\end{array}$ & $\begin{array}{l}\text { Mean submergence } \\
\text { duration (min) }\end{array}$ & $\%$ time submerged \\
\hline Radio/backpack b & Inter-nesting females & 9 & 23.7 & 16.7 & $(97.6)$ \\
\hline Radio/tether ${ }^{c}$ & Subadults & 2 & 126.0 & 12.7 & $(83.5)$ \\
\hline Radio/backpack ${ }^{\mathrm{d}}$ & Subadults & 2 & $(90.0)$ & $(27.0)$ & 95 \\
\hline Radio/tether ${ }^{\mathrm{e}}$ & Subadults & 16 & - & - & $1.7-95.1$ \\
\hline Radio/tether ${ }^{f}$ & Subadults & 7 & 18.5 & 8.4 & $95.7-97.6$ \\
\hline $\begin{array}{l}\text { Satellite/tether } \\
\text { and backpack }\end{array}$ & Post-nesting females & 14 & - & 18.1 & 96 \\
\hline Satellite/backpack ${ }^{\text {h }}$ & Subadults and adult & 4 & - & 33.7 & $58.9-98.5$ \\
\hline Satellite/backpack ${ }^{\mathrm{d}}$ & Adult & 1 & - & 60.2 & 94 \\
\hline
\end{tabular}

${ }^{a}$ As defined by Schmid $(1995,1998)$

${ }^{b}$ Mendonça and Pritchard (1986)

${ }^{\mathrm{c}}$ Byles (1988)

${ }^{\mathrm{d} G i t s c h l a g}$ (1996)

${ }^{e}$ Morreale and Standora (1998)

fPresent study

B Byles (1989)

${ }^{\text {h}}$ Renaud (1995)

Temperature is the main environmental factor influencing the daily activities of terrestrial animals (Cloudsley-Thompson 1961). However, daily temperature fluctuations in the aquatic environment are minimized owing to the higher thermal capacity of water. Consequently, the ecological significance of diel patterns in aquatic animals is less clear, though in most cases it is probably related to food acquisition (CloudsleyThompson 1961). The data available for marine turtles provide support for this supposition. Consistent diel activity patterns have been reported for subadult hawksbill, Eretmochelys imbricata, (van Dam and Diez 1998) and green turtles, Chelonia mydas, (Bjorndal 1980; Mendonça 1983; Ogden et al. 1983), but have not been observed in subadult loggerhead turtles, Caretta caretta, (Byles 1988) or subadult and post-nesting Kemp's ridley turtles (Byles 1988, 1989). The spongivorous hawksbill and herbivorous green turtle feed on sedentary food items that tend to be concentrated in certain areas. Both species forage during daylight and return to resting sites at night. By comparison, the carnivorous loggerhead and Kemp's ridley turtles feed on benthic invertebrates, particularly molluses by the former (Dodd 1988) and crabs by the latter (Shaver 1991), and their prey may be widely dispersed, nocturnally active, and relatively mobile. Nightly resting sites were not recorded for either species, indicating that they may be feeding throughout a 24-h period. Nocturnal feeding has also been hypothesized for inter-nesting leatherback turtles, Dermochelys coriacea, as their dive patterns were correlated with the diel migration of the zooplankton upon which they feed (Eckert et al. 1989).

A few telemetric studies of Kemp's ridley turtles have identified the timing of daily activities, but none has suggested reasons for these patterns. The activity patterns of Kemp's ridley turtles in the Cedar Keys may correspond to the activities of their prey. Although the turtles in the present study did not exhibit consistent diel patterns of movement, there was a trend for a higher rate of diurnal movement and the significantly longer submergence durations during the night suggest reduced nocturnal movement. Nevertheless, turtles also exhibited periods of little or no movement during all hours of the day and night. Animals engaged in equal activities throughout a $24-\mathrm{h}$ period are referred to as nychthemeral, and the adaptive significance of this type of pattern is that it allows for regular bouts of feeding, which in turn may maximize feeding efficiency (Maier and White 1998). If Kemp's ridley turtles continue to feed at night, they must be using olfactory or auditory cues to find their prey. These methods of prey detection may also be used during the day owing to the turbid waters within the study area. Stone crabs, Menippe spp., and blue crabs, Callinectes sapidus, were identified as important food items for Kemp's ridley turtles captured in the vicinity of Corrigan Reef (Schmid 1998). The stone crab is nocturnally active and capable of sound production by way of stridulating organs on the chela (Powell and Gunter 1968; Bender 1971). The possibility of auditory prey detection could be investigated by capturing turtles and holding them for fecal sample analysis, then exposing turtles that have ingested stone crabs to stridulation and recording their behavior in response to the sound. Telemetric studies of foraging blue crabs indicated that their movements were non-directed with no diel pattern (Hines and Wolcott 1990; Nye 1990), although an increase in diurnal movements was noted for premolt crabs (Wolcott and Hines 1990).

Chelonid turtles are ectothermic and this presumably influences their seasonal activities as thermoregulation is achieved by moving between contrasting thermal environments. The question remains as to whether the turtles from the Cedar Keys move southward along the coast as the nearshore water temperature decreases or move to the deeper, warmer waters offshore. Satellite telemetry has been employed to document the seasonal activity patterns of Kemp's ridley turtles along the Atlantic coast (Renaud 1995; Gitschlag 1996; Morreale and Standora 1998) and similar methods should be employed to investigate their winter activities in the northeastern Gulf of Mexico. 
Acknowledgements We thank Franklin Percival and Paul Zwick for their valuable contributions to this study; Larry Ogren and Wayne Witzell for their support; Edgar and Rosa Campbell for allowing unrestrained use of their facilities in Cedar Key; and Jamie Barichivich, Mike Cherkiss, Tracey Collins, and Lisa Gregory for their exemplary field assistance. Two anonymous reviewers provided constructive comments on earlier drafts of this manuscript Funding for this project was provided by the National Marine Fisheries Service (NMFS) Panama City and Miami Laboratories and NMFS grants to the Archie Carr Center for Sea Turtle Research. Research activities were conducted under U.S. Fish and Wildlife Service permit PRT-67379 and Florida Department of Environmental Protection permit 030. All animal care was in full compliance with the University of Florida Institutional Animal Care and Use Committee.

\section{References}

Ackerman BB, Leban FA, Samuel MD, Garton EO (1990) User's Manual for Program HOME RANGE. 2nd edn. Technical Report 15. Forestry, Wildlife and Range Experiment Station, University of Idaho, Moscow

Andersen DE, Rongstad OJ (1989) Home-range estimates of redtailed hawks based on random and systematic relocations. J Wild Manage 53: 802-807

Batschelet E (1981) Circular statistics in biology. Academic Press, New York

Bender ES (1971) Studies of the life history of the stone crab, Menippe mercenaria (Say), in the Cedar Key area. Masters thesis. University of Florida, Gainesville

Bjorndal KA (1980) Nutrition and grazing behavior of the green turtle Chelonia mydas. Mar Biol 56:147-154

Bjorndal KA, Bolten AB (1990) Goals for sea turtle research in the Gulf of Mexico with respect to the oil and gas industries. In Tucker and Associates (eds) Sea turtles and marine mammals of the Gulf of Mexico. Proceedings of a workshop beld in New Orleans, Louisiana, 1-3 August 1989. OCS Study MMS 90 0009 , pp 47-58

Byles RA (1988) Behavior and ecology of sea turtles from Chesapeake Bay, Virginia. Doctoral dissertation, Virginia Institute of Marine Science, College of William and Mary, Williamsburg

Byles RA (1989) Satellite telemetry of Kemp's ridley sea turtle, Lepidochelys kempi, in the Gulf of Mexico. In: Eckert SA Eckert KL, Richardson TH (eds) Proceedings of the Ninth Annual Workshop on Sea Turtle Conservation and Biology. NOAA Tech Memo, NMFS-SEFC-232, pp 25-26

Carr A, (1957) Notes on the zoogeography of the Atlantic sea turtles of the genus Lepidochelys. Rev Biol Trop 5:45-61

Carr AF, Caldwell DK (1956) The ecology and migrations of sea turtles: 1, results of field work in Florida, 1955. Am Mus Nov 1793:1-23

Cloudsley-Thompson JL (1961) Rhythmic activity in animal physiology and behaviour. Academic Press, New York

Colton DE, Alevizon WS (1983) Movement patterns of bonefish, Albula vulpes, in Bahamian waters. Fish Bull US 81:148-154

Daniel WW (1990) Applied nonparametric statistics, 2nd edn PWS-KENT, Boston

Danton C, Prescott R (1988) Kemp's ridley in Cape Cod Bay, Massachusetts-1987 field research. In: Schroeder BA (ed) Proceedings of the Eighth Annual Workshop on Sea Turtle Conservation and Biology. NOAA Tech Memo, NMFS-SEFC-214, pp 17-18

Dodd CK Jr (1988) Synopsis of the biological data on the loggerhead sea turtle Caretta caretta (Linnaeus 1758). US Fish Wildl Serv Biol Rep 88(14)

Eckert SA, Eckert KL, Ponganis P, Kooyman GL (1989) Diving and foraging behavior of leatherback sea turtles (Dermochelys coriacea). Can J Zool 67:2834-2840
Gitschlag GR (1996) Migration and diving behavior of Kemp's ridley (Garman) sea turtles along the U.S. southeastern Atlantic coast. J Exp Mar Biol Ecol 205:115-135

Gourley EV (1979) Rhythms. In: Harless M, Morlock H (eds) Turtles: perspectives and research. Wiley, New York, pp 509 520

Gruber SH, Nelson DR, Morrissey JF (1988) Patterns of activity and space utilization of lemon sharks, Negaprion brevirostris, in a shallow Bahamian lagoon. Bull Mar Sci 43:61-76

Hines AH, Wolcott TG (1990) Blue crab movement and feeding measured by ultrasonic telemetry. Bull Mar Sci 46:246

Krebs CJ (1989) Ecological methodology. HarperCollins, New York

Maier JAK, White RG (1998) Timing and synchrony of activity in caribou. Can J Zool 76:1999-2009

McNay RS, Morgan JA, Bonnell FL (1994) Characterizing independence of observations in movements of Columbian blacktailed deer. J Wildl Manage 58:422-429

Mendonça MT (1983) Movements and feeding ecology of immature green turtles (Chelonia mydas) in a Florida Lagoon. Copeia 1983:1013-1023

Mendonça MT, Pritchard PCH (1986) Offshore movements of post-nesting Kemp's ridley sea turtles (Lepidochelys kempi). Herpetologica 42:373-381

Morreale SJ, Standora EA (1998) Early life stage ecology of sea turtles in northeastern US waters. NOAA Tech Memo, NMFSSEFSC-413

Morrissey JF (1991) Activity space parameters, home range, diel activity rhythms, and habitat selection of juvenile lemon sharks Negaprion brevirostris (Poey). Doctoral dissertation, University of Miami, Coral Gables

Nieuwolt PM (1996) Movement, activity, and microhabitat selection in the western box turtle, Ornata luteola, in New Mexico. Herpetologica 52:487-495

Nixon AJ, Gruber SH (1988) Diel metabolic and activity patterns of the lemon shark (Negaprion brevirostris). J Exp Zool 248:1-6

Nye LA (1990) Telemetric analysis of foraging behavior by blue crabs. Bull Mar Sci 46:248

Ogden JC, Robinson L, Whitlock K, Daganhardt H, Cebula R (1983) Diel foraging patterns in juvenile green turtles (Chelonia mydas) in St. Croix United States Virgin Islands. J Exp Mar Biol Ecol 66:199-205

Otis DL, White GC (1999) Autocorrelation of location estimates and the analysis of radiotracking data. J Wildl Manage 63:1039-1044

Powell EH Jr, Gunter G (1968) Observations on the stone crab, Menippe mercenaria Say, in the vicinity of Port Aransas, Texas. Gulf Res Rep 2:285-299

Renaud MR (1995) Movements and submergence patterns of Kemp's ridley turtles (Lepidochelys kempii). J Herpetol 29:370374

Renaud MR, Carpenter JA, Williams JA, Manzella-Tirpak SA (1995) Activities of juvenile green turtles, Chelonia mydas, at a jettied pass in south Texas. Fish Bull US 93:586-593

Reynolds TD, Laundré JW (1990) Time intervals for estimating pronghorn and coyote home ranges and daily movements. J Wildl Manage 54:316 322

Schmid JR (1995) Marine turtle populations on the east-central coast of Florida: results of tagging studies at Cape Canaveral, Florida, 1986-1991. Fish Bull US 93:139-151

Schmid JR (1998) Marine turtle populations on the west-central coast of Florida: results of tagging studies at the Cedar Keys, Florida, 1986-1995. Fish Bull US 96:589-602

Shaver DJ (1991) Feeding ecology of wild and head-started Kemp's ridley turtles in South Texas waters. J Herpetol 25:327-334

Standora EA, Morreale SJ, Estes R, Thompson R, Hilburger M (1989) Growth rates of juvenile Kemp's ridleys and their movement in New York waters. In: Eckert SA, Eckert KL, Richardson TH (eds) Proceedings of the Ninth Annual Workshop on Sea Turtle Conservation and Biology. NOAA Tech Memo, NMFS-SEFC-232, pp 175-177 
Swihart RK, Slade NA (1985a) Testing for the independence of observations in animal movements. Ecology 66:1176-1184

Swihart RK, Slade NA (1985b) Influence of sampling interval on estimates of home-range size. J Wildl Manage 49:1019-1025

Swihart RK, Slade NA (1986) The importance of statistical power when testing for independence in animal movements. Ecology $67: 255-258$

Thompson N, Henwood T, Epperly S, Lohoefner R, Gitschlag G, Ogren L, Mysing J, Renaud M (1990) Marine turtle habitat plan. NOAA Tech Memo, NMFS-SEFC-255

U.S. Fish and Wildlife Service and National Marine Fisheries Service (1992) Recovery plan for the Kemp's Ridley Sea Turtle
(Lepidochelys kempii). National Marine Fisheries Service, St. Petersburg

Van Dam RP, Diez CE (1998) Home range of immature hawksbill turtles (Eretmochelys imbricata (Linnaeus)) at two Caribbean islands. J Exp Mar Biol Ecol 220:15-24

White GC, Garrott RA (1990) Analysis of wildlife radio-tracking data. Academic Press, New York

Wolcott TG, Hines AH (1990) Uitrasonic telemetry of small-scale movements and microhabitat selection by molting blue crabs (Callinectes sapidus). Bull Mar Sci 46:83-94 